\title{
Pain, Struggle, and Hope: An African American Reading of Mildred D. Taylor's The Land*
}

\author{
YANG Chun \\ China Youth University of Political Studies, Beijing, China
}

\begin{abstract}
The Land (2001) is a powerful coming-of-age story by African-American writer Mildred D. Taylor. Through vividly depicting the mental and physical pains suffered by black people as well as the undying hope of protagonist Paul in the struggle of achieving social and economic independence by obtaining a land of his own, Mildred D. Taylor not only pungently exposes the evils of racism but also successfully builds up positive image of black character in The Land. Based on African American criticism theory and close reading of the text, the present paper aims at exploring the central themes of pain, struggle, and hope presented in the novel with the hope of interpreting the historical and realistic significance of the novel.
\end{abstract}

Keywords: The Land, African American criticism, pain, struggle, and hope

\section{Introduction}

Mildred D. Taylor is an African-American writer well-known for her works exploring the pain and struggle faced by African Americans in the Deep South. The Land (2001) is the fifth and final book of her Logan Family saga. Since its publication, this book has won her numerous awards, including 2001 Los Angeles Times Book Prize; 2002 Coretta Scott King Author Awards; PEN Award for Chikdren's Literature, and 2002 Scott O’Dell Award for Historical Fiction.

The protagonist in The Land is Paul-Edward Logan, a child of a white prosperous landowner and a black former slave. Being bi-racial, life for him is not easy. Black people distrust him because he looks white. White people discriminate against him when they learn of his black heritage. Even within his own family he faces betrayal and degradation. Paul incessantly suffers from the pain of unbelonging. Several years later, tired of obeying his father, Edward Logan, Paul, and his intimate friend Mitchell run away and start their journey of struggle. After experiencing many ups and downs, Paul finally possesses the land and lives the life he wants.

Through vividly depicting the mental and physical pains suffered by black people as well as the undying hope of protagonist Paul in the struggle of achieving social and economic independence by obtaining a land of his own, Mildred D. Taylor not only pungently exposes the evils of racism but also successfully builds up positive image of black character in The Land. Based on African American criticism theory and close reading of the text, the present paper aims at exploring the central themes of pain, struggle and hope presented in the novel with the hope of interpreting the historical and realistic significance of the novel.

\footnotetext{
* Acknowledgements: This paper is supported by China Youth University of Political Studies. YANG Chun, associate professor, M.A., Foreign Language Department, China Youth University of Political Studies.
} 


\section{Pain}

In her notes to the reader Mildred D. Taylor once said:

All of my books are based on stories told by my family, and on the history of the United States. In my writing I have attempted to be true to those stories and the history. I have included characters, incidents, and language that present life as it was in many parts of the United States before the Civil Rights Movement. Although there are those who wish to ban my books because I have used language that is painful, I have chosen to use the language that was spoken during the period, for I refuse to whitewash history. The language was painful and life was painful for many African-Americans, including my family. I remember the pain. (Taylor, 2001, p. 375)

The pain presented in The Land honestly manifests the true life of black people several years after the American Civil War when racism was rampant and colored people were systematically discriminated by whites.

The novel begins with Paul's childhood. As a colored boy who looked almost white, Paul has a relatively happy childhood. His father Edward Logan, a much-respected man, not only acknowledges that Paul and his sister, Cassie are his children but also raises them pretty much the same as his white children, which is rather rare at that time. Paul's white brothers Robert, Hammond, and George are also very nice to him and protect him when he is bullied by other children. Life is good when Paul is a little boy. But as he grows older, he begins to notice that he is not always treated the same as his white brothers.

When folks came over to supper, Cassie and I weren't allowed to sit at our daddy's table, while Robert, Hammond, and George still did. Whenever there was any socializing at the place, we weren't allowed the roam of the house, but had to stay put in the kitchen, where my mamma and others serve up preparations for my daddy's guests. (Taylor, 2001, p. 48)

When Paul is a little boy, being sent off to the kitchen to eat or outside to play when the visitors come for their socializing does not bother him. But as he grows older, he begins to feel the segregation, the hatred and the pain behind this unequal treatment:

Robert's grandma on his mamma's side always hated the fact my daddy allowed Cassie and me to sit at his table and enjoy the life she felt was owed only to her daughter's children... I remember she was always hard on my mama, on Cassie and me. When my daddy was away during mealtime, she would send Cassie and me from the table. ...Worse than that, she would sometimes say cruel things to us. ...Robert's grandmother died a few years later, but there were always others who sat at our daddy's table who thought the same as she had about Cassie and me. I suppose my daddy could have been trying in part to protect Cassie and me from all those people, while saving his own social standing, but even thinking of that possibility didn't ease our pain. We'd been sent off just the same. (Taylor, 2001, pp. 49-50)

Robert's grandma's attitude towards Cassie and Paul is the typical examples of everyday racist behavior exhibited by white people. The harm brought by this emotionally draining and pain-provoking form of racism sows the seeds of struggle in little Paul's heart.

When Paul is about to reach his manhood, an incident between Robert and Paul imprints lifelong pain on Paul's memory. Robert is the youngest of Paul's white brothers. Since they are about the same age, they spend their whole childhood playing together and learning from each other like a carrot and pea. When Paul is a little boy, he is proud of the loyal brotherhood with Robert. But things change with time passing by. Different racial status establishes an invisible gap between them and conflict is unavoidable.

On Christmas Eve, both Paul and Robert go home. Robert invites his white friends Percy and Christian to ride Paul's favorite horse Appaloosa without Paul's permission. Paul is rather angry with Robert and his friends: 
I spat out angrily. "What you do to this horse? How could you ride him down this way? Use a whip on him? Robert! How could you be so stupid as to ever let a Waverly ride my Appaloosa?"

"Your Appaloosa?" said Robert.

"Stupid?" exclaimed Christian. "Boy, you calling a white man stupid?"

...

"Robert, you gonna let this boy talk that way to you?" Percy cried again.

"You don't do something about this smart-talking white nigger, I will!" vowed Christian.

Robert didn't object to the word this time. I took note of that, then turned with Appaloosa and headed off the road into the forest. (Taylor, 2001, p. 79)

Robert tried to stop Paul from going to the forest with Appaloosa but in vain. In a rage, Robert hits Paul a sharp uppercut to his jaw. Then he came to Paul again and knocked him to the ground with a wild rage, flailing at him. Paul was mad, too. Robert had turned on him, and it was a hurt more than he could bear. He slammed at Robert with a fury.

When Paul's daddy knew what happened between Robert and Paul, he whipped Paul despite Paul's protest:

"Who said it was about fair?" My daddy's eyes settled on mine, and I took off the clothes. I stripped bare as they all watched. I stripped bare and felt as I had never felt before, not just naked, but worn and like an old shoe, soleless. My daddy raised his strap, and then strap cut into me good, but I didn't cry out and I let no tears fall. He let the strap fall again and again across my back, and I just stood there in my nakedness gazing out across the land I had once thought was mine, feeling my humiliation and thinking on the family I had once thought was mine. (Taylor, 2001, p. 83)

Daddy's whipping totally destroys Paul's illusion of his happy life. Now he realizes that he lives in a white man's country, and as long as he stays colored, he will never get any fair treatment from whites' dominant world. To save face with two white friends Robert betrays Paul which hurts him deeply. Paul feels rather sad since he lost his brother and his best friend. He was 13 years old by then, and he figured as long as he lived, he could never forgive Robert for his betrayal.

As an important concept in African American criticism, “institutionalized racism” refers to,

The incorporation of racist policies and practices in the institutions by which a society operates: for example, education; federal, state, and local governments; the law, both in terms of what is written on the books and how it is implemented by the courts and by police officials; health care, which can be racially biased in everything from the allocation of research dollars to the locations of hospitals to the treatment of individual patients; and the corporate world, which often practices racial discrimination in its hiring and promotion despite whatever equal-opportunity polices it officially claims to have. (Tyson, 2006, p. 361)

In The Land, because of "institutionalized racism", Paul and his white brothers could not go to the same school and receive the same education; because of "institutionalized racism", Paul and his sister could not share the same table with his family members when visitors came, and because of "institutionalized racism", Paul suffered humiliation and unjust treatment from both whites and blacks since black people distrust him because he looks white and white people discriminate against him when they learn of his black heritage. Paul's suffering and pain represents the pain of all the colored people who were discriminated, segregated and persecuted by whites in the 19th century south. "Institutionalized racism" is the root of all their pains.

\section{Struggle and Hope}

In the second part of the novel, Paul runs away from home with his black friend, Mitchell. The pain he 
suffered in his childhood teaches him the lesson that in order to survive in a hostile world, he needs to struggle against adversity and owns his own land.

What I wanted was land. I wanted land like my daddy's. In a way, I suppose, I was driven by the thought of having land of my own. In my early years, before I truly realized my two worlds, I had figured that I'd always live on my daddy's land, that my daddy's land would be mine and I'd always be a part of it. When I discovered that wouldn't be, I created my own land in my mind, I knew that land was what I had to have. (Taylor, 2001, p. 142)

Paul pays a lot in order to realize his dream of having a land of his own. He works hard and tries every method to save money. He trains and races horses, making money as a skilled carpenter. He works seven days a week to clear the land, chopping the trees, hacking the branches, burning the brushes, and planting cotton although the bank refuses to loan him money and whites exploit him, insult him, cheat him, and injure him.

I worked seven days each week. I chopped the trees and I tended cotton. I worked with fever and I worked with pain. I worked as I had with Mitchell before Caroline came on the forty. I pushed myself until I could push myself no further. Everything in me needed to keep my promise to Mitchell and to myself. I needed to secure this acreage so that I could buy J. T. Hollenbeck's land, and I needed to have a place for Caroline and her baby. Once that was done, then I figured I could take the time to rest. (Taylor, 2001, p. 329)

After experiencing many ups and downs and making great sacrifice, Paul finally had the land of his own. To him, the land is not only a place to provide food and shelter for him but also a symbol of independence and hope.

In African American criticism, "institutionalized racism" refers to the fact that,

The dominant society racializes [defines the racial characteristics of] different minority groups [in different ways] at different times, in response to its shifting needs. For example, it suited the needs of white plantation owners before the Civil War to depict Africans as simple-minded, in need of white supervision lest they revert to their "heathen" ways, and as happy to serve white people. This mythical stereotype helped justify, the plantation owners believed, their enslavement of Africans. Later, especially whenever they were thought to be in competition with whites for jobs, African Americans were stereotyped as threatening, prone to violence, and, often at the same time, lazy. (Tyson, 2006, p. 375)

Depending on the needs of white society, the stereotypes of African American in American history are almost negative images as W. Lawrence Hogue points out.

In the United States, the African American is constituted in a white/black binary of signification that defines whites as normative and superior and that represents black as victim, as inferior, as devalued Other, or since the 1960s, as the Same as whites. This binary, which can be traced to the European Renaissance, is reproduced and reinforced not only by mainstream American society but also by the African American sociopolitical mission of racial uplift and its literary and historical extensions: The canon of African American literature and the classic African American historical emancipator narrative. (Hogue, 2003, p. 1)

While in The Land, through depicting the struggle of Paul to achieve economic and social independence by obtaining the land of his own, Mildred D. Taylor paints a truer picture of black people who harbor endurance, love, self-pride, wisdom, perseverance, and hope. The characterization of the positive image of Paul to some degree corrects the negative stereotypes of African American.

\section{Conclusion}

When talking about her wish in writing, Mildred D. Taylor once claimed that,

Since writing my first book, Song of the Tree, it has been my wish to have readers walk in the shoes of the Logan 
family, who are based on my family, and to feel what they felt. It has been my wish that by understanding this family and what they endured, there would be further understanding of what millions of families endured, and there would also be a further understanding of why there was a Civil Rights Movement, a movement that changed our nation. (Taylor, 2001, p. 375)

As an African-American writer, Mildred D. Taylor is in a better position to write and speak about race and racism because all of her books are based on stories told by her family members who have experienced racism directly. Nowadays, even though black people and other minority groups enjoy the same civil rights as whites under the civil rights laws, there still exists racial prejudice and discrimination against black people and other minority groups. The honest depiction of the pain suffered by black people under the "institutionalized racism" in the 19th century South as well as the struggle and hope presented in The Land will arouse more and more people's concern of the racial problems existing in present American society. This is Mildred D. Taylor's wish and this is the historical and realistic significance of The Land.

\section{References}

Bakan, A. B., \& Dea, E. (2014). Theorizing anti-racism: Linkages in Marxism and critical race theories. Toronto Buffalo London: University of Toronto Press.

Boyagoda, R. (2008). Race, immigration, and American identity in the fiction of Salman Rushdie, Ralph Ellison, and William Faulkner. New York: Routledge.

Delgado, R., \& Stefancic, J. (2000). Critical race theory: The cutting edge (2nd revised ed.). Philadelphia, USA: Temple University Press.

Hogue, W. L. (2003). The African American male, writing, and difference: A polycentric approach to African American literature, criticism, and history. New York, NY: State University of New York Press.

Taylor, M. D. (2001). The land. New York: Penguin Group (USA) Inc..

Taylor, M. D. (n.d.). The Land and other books. Retrieved from https://www.teachervision.com/reading/multicultural-literature/31177.html?page=2\&detoured=1

Tyson, L. (2006). Critical theory today: A user-friendly guide (2nd revised ed.). New York, USA: Routledge Taylor \& Francis Group.

Zamudio, M. M., Russell, C., Rios, F. A., \& Bridgeman, J. L. (2011). Critical race theory matters: Education and ideology. New York, NY: Routledge. 